\title{
PROBLEMS OF PUBLIC-PRIVATE PARTNERSHIP IN UKRAINE AND WAYS OF SOLVING THEM
}

\author{
Maksim LEVOCHKIN ${ }^{1}$ \\ Kyiv National Economic University named after Vadym Hetman, Ukraine
}

\begin{abstract}
The article reveals the essence and role of public-private partnership (PPP). It is established that a public and private partnership is a powerful and promising tool of social and economic development at both the regional and local levels, as well as a means of raising funds to projects. The legal regulation of public and private partnership in Ukraine and its shortcomings are determined. It was found that the legislation contains a lot of controversial issues related to: communication problems between the partners; legislative and regulatory issues; financing problems. The number of the PPP projects in Ukraine is presented by sectors and investment in projects of public-private partnership is shown. It was determined that during 1992-2012, 58 PPP projects have been implemented in Ukraine, or $7.03 \%$ of the total number of implemented projects. The structure of PPP projects implemented in Ukraine is shown, where the lion's share is taken by the energy sector $(71 \%)$, telecommunications (24\%), transport (2\%), water supply and drainage (3\%). The problems that hinder the development of public and private partnership in Ukraine were identified, namely the shortage of highly qualified specialists who are able to develop public-private partnership in the future - both on the part of business, and country; shortage of projects of public-private partnership as well as appropriate banking requirements to them; disinclination of business for stimulating the development of public-private partnership, since the number of private operators is negligible in a very few sectors; inability of public authorities to maintain partner relationships and the implementation of PPP projects; shortcomings of the legislative framework (such as concession) and mismatch of enforcement activity; little activity of the regions in showing initiative to develop and implement PPP projects; inability to attract investment in long-term PPP projects, etc. The ways of improving the implementation of public and private partnership in Ukraine according to the Concept of Development of Public and Private Partnership in Ukraine are identified, including the identification of priority areas for the development of PPPs; improving the investment climate and business environment in the context of the development of PPPs; the development of the authorized state body responsible for the development of PPPs; strengthening the functions of local authorities in the area of PPPs; improving funding mechanisms for PPP projects; activation of the development institutions in the PPP management system; elimination of contradictions and shortcomings of the legal framework of PPP; improving the cooperation of the authorities with civil society institutions for the implementation of PPP projects. Purpose. This article provides for achieving the following objectives: 1) the study of problems of public-private partnership in Ukraine; 2) identification of solutions thereto. The subject of the research is the mechanism of public-private partnership, its problems and solutions thereto. Methodology. In this work the following general scientific and special methods of study were used: comparative and legal, historical, dialectical, analytical and synthetic, formal and logical and statistical methods. Results. The findings allowed drawing specific suggestions for overcoming the problems of public and private partnership in Ukraine. The practical significance of the findings is that the article thoroughly investigated the situation and problems of public and private partnership in Ukraine. Value/originality. This article is a completely original investigation, is practical and can be used for further scientific work.
\end{abstract}

Key words: public-private partnership, state, private sector project.

JEL Classification: P26, P27, L32

\footnotetext{
Corresponding author:

${ }^{1}$ Department of Political Economy, Kyiv National Economic University named after Vadym Hetman.

E-mail: 1010bios1989@gmail.com
} 


\section{Introduction}

The development of public-private partnership in Ukraine is in the initial stage, as evidenced by the low share of private investment in PPP projects, the use of public-private partnership not in all sectors of the national economy, lack of effectiveness of the implementation of PPP projects (in the field of education, health care).

The key issues of the implementation of PPP projects in the Ukraine are the following: poor institutional environment, imperfect regulatory support, scanty profit attractiveness of projects for private investors, the lack of incentive mechanisms in the implementation of PPP projects. In addition, at the present stage of PPP establishment, the questions concerning the need for applying new areas of the implementation of PPP projects become extremely topical in Ukraine.

The problems of the formation of public-private partnership are studied in the research works of such scholars as Butnyk O.O. (Butnyk, 2014), Honcharenko N.V. (Honcharenko, 2015), Didchenko A.I. (Didchenko, 2011), Kalinko I.V. (Kalinko, 2015),

Table 1

The number of PPP projects in Ukraine in 1992-2012 by sectors*

\begin{tabular}{|c|c|c|c|c|c|c|}
\hline \multirow[b]{2}{*}{ No. } & \multirow[b]{2}{*}{ Year } & \multicolumn{4}{|c|}{ Sector } & \multirow[b]{2}{*}{ Total } \\
\hline & & 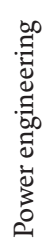 & 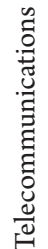 & 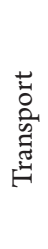 & 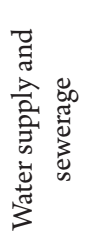 & \\
\hline 1 & 1992 & 0 & 1 & 0 & 0 & 1 \\
\hline 2 & 1993 & 0 & 1 & 0 & 0 & 1 \\
\hline 3 & 1994 & 0 & 0 & 0 & 0 & 0 \\
\hline 4 & 1995 & 0 & 0 & 0 & 0 & 0 \\
\hline 5 & 1996 & 0 & 3 & 0 & 0 & 3 \\
\hline 6 & 1997 & 0 & 2 & 0 & 0 & 2 \\
\hline 7 & 1998 & 6 & 1 & 0 & 0 & 7 \\
\hline 8 & 1999 & 0 & 0 & 0 & 0 & 0 \\
\hline 9 & 2000 & 0 & 1 & 0 & 0 & 1 \\
\hline 10 & 2001 & 6 & 3 & 0 & 0 & 9 \\
\hline 11 & 2002 & 1 & 0 & 0 & 0 & 1 \\
\hline 12 & 2003 & 0 & 0 & 0 & 1 & 1 \\
\hline 13 & 2004 & 0 & 0 & 0 & 0 & 0 \\
\hline 14 & 2005 & 0 & 0 & 0 & 0 & 0 \\
\hline 15 & 2006 & 1 & 1 & 0 & 0 & 2 \\
\hline 16 & 2007 & 1 & 0 & 0 & 0 & 1 \\
\hline 17 & 2008 & 1 & 0 & 0 & 1 & 2 \\
\hline 18 & 2009 & 0 & 0 & 1 & 0 & 1 \\
\hline 19 & 2010 & 4 & 0 & 0 & 0 & 4 \\
\hline 20 & 2011 & 5 & 1 & 0 & 0 & 6 \\
\hline 21 & 2012 & 16 & 0 & 0 & 0 & 16 \\
\hline 22 & Разом & 41 & 14 & 1 & 2 & 58 \\
\hline
\end{tabular}

* composed by the author based on the Database of Public-Private Partnership Projects in the World
Maslennikov A.M. (Maslennikov, 2011), Moskalenko S.A. (Moskalenko,2011), Pavlova G.A. (Pavlova, 2011), Pavliuk K.V. (Pavliuk, 2010), Pavliuk S.M. (Pavliuk, 2010), Pavliuk I.V. (Pavliuk, 2010), Sulyma N.M. (Siduniak, 2014) et al.

Despite quite a large number of studies on this subject matter, to date there is no single approach to defining the key areas of addressing systemic issues of public-private partnership in Ukraine. Accordingly, this research paper aims at studying the problems of public-private partnership in Ukraine and ways of solving them.

\section{Research findings}

Public-private partnership is an effective tool for economic and social development at the regional and local levels, a means of raising funds for projects where the state and local authorities are trying to maintain control and to establish cooperation with private investors (Didchenko, 2011).

According to the Law of Ukraine "On Public-Private Partnership" No. 2404-VI dated July 1, 2010, the publicprivate partnership is defined as a partnership between the state of Ukraine, the Autonomous Republic of Crimea, territorial communities represented by the relevant state authorities, local governments (public partners) and legal entities, except state and municipal enterprises, or individual entrepreneurs (private partners), which is carried out on a contract basis in accordance with the procedure established by this Law and other regulations (The Law of Ukraine "On Public-Private Partnership" dated July 1, 2010).

Public-private partnership can be defined as a form of interaction between the public partner represented by the state, local communities and local governments, and the private partner - legal persons or individual entrepreneurs aimed at achieving specific economic outcomes, such as, for example, the development of infrastructure projects (Maslennikov, 2011).

In the current economic conditions, PPP is an alternative to privatization of state and municipal property, because it combines the advantages of public and private sectors, in particular:

- Social responsibility, social accountability and priority of environmental standards in the activities; it is characteristic of the state and municipal organizations;

- Financial resources, technology, managerial efficiency and entrepreneurial spirit of the private sector (Butnyk, 2014).

PPP allows not simply implementing the project, but implementing it efficiently, on time and without delay, thus enhancing the quality of public services provided to the population and increasing the efficiency of infrastructure management, promotes the effective development of state property. Thus, the mechanisms of PPP allow successful using of the experience and expertise of the private sector, while maintaining state control over the assets (Pavliuk, 2010). 
As a general rule, a return on investment within PPP is much higher than in traditional schemes of implementation of various social projects. This, in turn, helps to successfully implement large infrastructure projects, which otherwise could hardly be implemented (Pavliuk, 2010).

In 1992-2012, $58 \mathrm{PPP}$ projects were implemented in Ukraine (Table 1), or $7.03 \%$ of the total number of completed projects (820).

This figure is more than one and a half times higher than the regional average. In addition, if in the region as a whole, the number of projects in 2012 decreased in comparison with the previous year, in Ukraine it has grown and has the largest figure in the history of this activity (The Database of Public-Private Partnership Projects in the World).

The structure of total implemented PPP projects includes power engineering (71\%), telecommunications $(24 \%)$, transport $(2 \%)$, water supply and sewerage (3\%) (Figure 1).

The total volume of investment in the projects of publicprivate partnership in Ukraine amounted to 14.16 billion US dollars for 1992-2012, the amount of investment obligations of the state partners is 1.8 billion US dollars, see Table 2. This figure is quite significant in comparison with countries in the region.

It should also be noted that even in those years when new PPP projects have not started, the investment flow through long-term projects did not have a zero value. At the same time, insignificant, from our point of view, participation of the state in the funding of projects should be noted. Most of the period, the state did not provide financial assistance to PPP projects, it has started to do so more or less consistently in 2009. This trend indicates a lack of attention that the state pays to partnership with the private sector (Braylovsky, 2014).

Today, the system of legislative support of the PPP mechanisms consists of such legislative acts: the Law of Ukraine "On Public-Private Partnership", "On Financial Leasing”, “On Concessions”, “On Concessions for Construction and Operation of Motor Roads", "On Public Property Management”, “On Peculiarities of Transferring Facilities of Central Water Supply, Heat Supply and Sewerage Being Communal Property for Lease or Concession", "On Amendments to Certain Legislative Acts of Ukraine Regarding Implementation of Joint Activities", "On Peculiarities of Transferring the Facilities
Table 2

Investments in PPP projects in Ukraine in 1992-2012 (million USD)*

\begin{tabular}{|c|c|c|c|}
\hline No. & Year & $\begin{array}{c}\text { Government } \\
\text { investment obligations }\end{array}$ & Total \\
\hline 1 & 1992 & 0 & 11 \\
\hline 2 & 1993 & 65 & 72 \\
\hline 3 & 1994 & 0 & 10 \\
\hline 4 & 1995 & 0 & 18 \\
\hline 5 & 1996 & 65 & 317 \\
\hline 6 & 1997 & 9 & 187 \\
\hline 7 & 1998 & 0 & 331 \\
\hline 8 & 1999 & 0 & 242 \\
\hline 9 & 2000 & 0 & 206 \\
\hline 10 & 2001 & 160 & 415 \\
\hline 11 & 2002 & 0 & 206 \\
\hline 12 & 2003 & 0 & 370 \\
\hline 13 & 2004 & 0 & 738 \\
\hline 14 & 2005 & 0 & 1,507 \\
\hline 15 & 2006 & 4 & 869 \\
\hline 16 & 2007 & 41 & 1,429 \\
\hline 17 & 2008 & 0 & 1,566 \\
\hline 18 & 2009 & 54 & 1,185 \\
\hline 19 & 2010 & 85 & 501 \\
\hline 20 & 2011 & 1,320 & 2,816 \\
\hline 21 & 2012 & 35 & 1,164 \\
\hline 22 & Pa30M & 1,838 & 14,161 \\
\hline & & & \\
\hline
\end{tabular}

*composed by the author based on the Database of Public-Private Partnership Projects in the World

of State-Owned Fuel and Energy Complex for Lease or Concession", "On Transparency of Use of Public Funds", and others.

Considering that the experience of public-private partnership in Ukraine is insignificant, legislation contains a lot of controversial issues related to: communication problems between the partners; legislative and regulatory issues; funding problems (Resolution of the Cabinet of Ministers of Ukraine On the Approval of the Concept of the Development of Public-Private Partnership in Housing and Communal Services dated September 16, 2009). These legislative acts are also far from ideal (in terms of regulation of relations in PPP) and require significant improvements. And Ukraine cannot boast of some successful projects in the field of PPP (Butnyk, 2014).

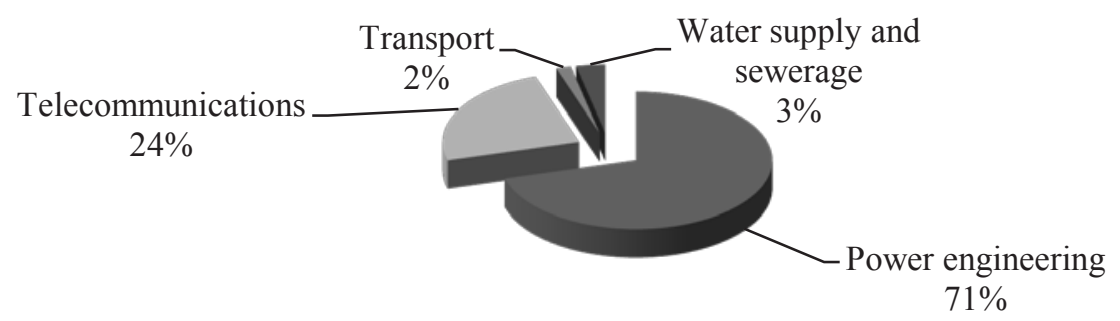

Fig. 1. The structure of implemented PPP projects*

* composed by the author based on the Database of Public-Private Partnership Projects in the World 
Today, specialists identify a number of problems in the legal framework for the implementation of public-private partnership that need to be addressed. Firstly, the issues in the field of protection of intellectual property rights and technology transfer in the framework of public-private partnership are not resolved.
Secondly, for the efficiency of public-private partnership we need political stability not only enshrined in law, but practically implemented. Third, a legal mechanism for the use of corporate instruments to attract funding is not established, this requires the development of a system of partner interaction in the form of joint-stock companies (Didchenko, 2011).

Table 3

The ways of improving the implementation of PPP in Ukraine, according to the Concept of the Development of Public-Private Partnership in Ukraine for 2012-2017*

\begin{tabular}{|c|c|c|}
\hline No. & Ways & Activities \\
\hline 1 & $\begin{array}{l}\text { Identification of priority areas of the } \\
\text { activity for the development of PPP }\end{array}$ & $\begin{array}{l}\text { In the future development PPP should apply to: scientific, technical and innovation } \\
\text { sphere; information sphere; agro-industrial complex; forestry. }\end{array}$ \\
\hline 2 & $\begin{array}{l}\text { Improving of the investment climate } \\
\text { and business environment in the } \\
\text { context of PPP development }\end{array}$ & $\begin{array}{l}\text { Increasing the transparency of the licensing system and reduction of bureaucratic barriers. } \\
\text { Regulating the inspections and regulatory procedures (standardization and } \\
\text { certification). } \\
\text { Simplification of property registration procedures. } \\
\text { Creating favourable conditions for the use of land plots within the framework of PPP } \\
\text { projects. } \\
\text { Ensuring transparency in relations between private and public partners in the } \\
\text { preparation and implementation of PPP projects. } \\
\text { Focusing government efforts on the implementation of PPP projects and the formation } \\
\text { of effective feedback in the relationship of the state with the private sector. }\end{array}$ \\
\hline 3 & $\begin{array}{l}\text { Establishment of authorized state body } \\
\text { responsible for PPP development }\end{array}$ & $\begin{array}{l}\text { Formation of strategic directions of PPP development in Ukraine. } \\
\text { Methodical and advisory support to the projects. } \\
\text { Harmonization of the analysis of PPP effectiveness. } \\
\text { The mechanism of clear coordination of the activities of central authorities for the } \\
\text { implementation of PPP projects at the national level. } \\
\text { The transparency of activities in the field of PPP, including through the establishment of } \\
\text { the Public Board at the Ministry of Economic Development and Trade of Ukraine. }\end{array}$ \\
\hline 4 & $\begin{array}{l}\text { Strengthening the functions of local } \\
\text { authorities in the area of PPP }\end{array}$ & $\begin{array}{l}\text { Ensuring effective implementation of projects through the development of a single } \\
\text { management mechanism of selection, examination, coordination and implementation } \\
\text { of the project with the assistance of appropriately qualified specialists }\end{array}$ \\
\hline 5 & $\begin{array}{l}\text { Improving mechanisms for funding } \\
\text { PPP projects }\end{array}$ & $\begin{array}{l}\text { Building relationships with international development institutions and fostering the } \\
\text { formation of national development institutions which activities should be aimed } \\
\text { at achieving the priorities of innovative renovation of the economy using modern } \\
\text { approaches to risk management }\end{array}$ \\
\hline 6 & $\begin{array}{l}\text { Activation of development institutions } \\
\text { in PPP management system }\end{array}$ & $\begin{array}{l}\text { Increasing the efficiency of using budgetary funds, the intensification of involvement } \\
\text { of the development institutions in PPP projects, the expansion of long-term project } \\
\text { funding tools, and the like. }\end{array}$ \\
\hline 7 & $\begin{array}{l}\text { Eliminating contradictions and } \\
\text { shortcomings of the PPP regulatory } \\
\text { framework }\end{array}$ & $\begin{array}{l}\text { Improvement of the Law in terms of: } \\
\text { - more clear determination of powers of the authorities involved in PPP projects at all } \\
\text { stages, both at central and local levels; } \\
\text { - extension of the time horizon of relations in the framework of PPP; } \\
\text { - clarifying the PPP signs regarding the delegation of functions and powers of the state } \\
\text { in relation to the development of infrastructure and provision of public services to the } \\
\text { private sector; } \\
\text { - clarifying the list of areas of application of PPP agreements; } \\
\text { - introduction of the possibility of implementing an institutional partnership, and hence } \\
\text { the creation of a special joint venture project company, authorizing the state (municipal) } \\
\text { enterprises to be parties of PPP agreements on the side of the public partner; } \\
\text { - harmonization of provisions of the Law with the provisions of special laws regulating } \\
\text { the contractual relationship between the state and the private sector in the field of } \\
\text { concessions, joint ventures, leases, product distribution, etc. }\end{array}$ \\
\hline 8 & $\begin{array}{l}\text { Improving cooperation between the } \\
\text { authorities and the institutions of civil } \\
\text { society on the implementation of PPP } \\
\text { projects }\end{array}$ & $\begin{array}{l}\text { Activation of public involvement in the preparation and implementation of PPP } \\
\text { projects at the state and local levels. In this context, it is necessary to develop } \\
\text { mechanisms of interaction between the authorities and civil society institutions in the } \\
\text { direction of engaging society in the discussion, examination and monitoring of the } \\
\text { implementation of PPP projects on a permanent basis. }\end{array}$ \\
\hline
\end{tabular}

*composed by the author based on the Concept of the Development of Public-Private Partnership in Ukraine for 2012-2017, 2011 
Therefore, using international experience of PPP for the benefit of the Ukrainian economy is quite an effective government initiative. Moreover, we really need this expertise, given the current state of industrial infrastructure - power engineering, motor roads and railways, ports, airports, pipelines. Fixed assets are extremely worn out, over the last 20-30 years there was almost no investment in infrastructure, and no construction of new facilities took place. Its current state is a source of possible structural, technological and other crises and disasters (Butnyk, 2014).

The problem of funding is a major obstacle to the implementation of PPPs, especially small and mediumsized projects. The high cost of bank funding in Ukraine and the lack of access to other forms of funding restrains investment in PPP infrastructure projects. After all, under adverse conditions in the country, reliable state support for investment projects cannot be provided. Most entrepreneurs do not trust governmental authorities. There are also significant external risks, which the state cannot protect the private partner from (Siduniak, 2014).

Thus, today there are many obstacles to the development of public-private partnership in Ukraine; the main ones are the following:

1. Lack of experienced personnel that could promote public-private partnership - from both the business and the state sides.

2. Lack of attractive projects compliant with bank requirements.

3. Unreadiness of the private sector: a small number of private operators in a very small number of sectors. Attitude to public-private partnerships and concessions among the Ukrainian businesses as the projects with extremely high risks and low returns, uncertainty about future conditions.

4. Unreadiness of authorities for the partner relations and implementation of public-private partnership projects.

5. Gaps and constraints of legislation (in particular, in the field of concession) and the lack of enforcement practice.

6. Lack of a regional activity both in the initiation of projects and their implementation.

7. Unreadiness to invest in long-term projects, and others (Pavlova, 2011).

The main problems of state support in the field of publicprivate partnership are the following (Resolution of the Cabinet of Ministers of Ukraine On the Approval of the Concept of the Development of Public-Private Partnership in Ukraine for 2013-2018 dated August 14, 2013):

- deficit of budget funds and the complexity of state support mechanism;

- lack of annual funding of long-term projects of publicprivate partnerships;

- uncertainty of the methodology of providing state support in the framework of the implementation of publicprivate partnership projects;
- incompliance of principles and approaches in the field of public-private partnership with international principles; - limited possibilities of obtaining government guarantees for the implementation of public-private partnership projects at the local level.

These problems should be solved with a focus on the best European and international practices, taking into account the current crisis trends, through the Concept of the Development of Public-Private Partnership in Ukraine for 2012-2017, 2011:

- identification of priority areas for the development of PPP in Ukraine;

- improving the investment climate and business environment in the context of the development of PPPs; - establishment of the authorized state body responsible for PPP development in Ukraine;

- strengthening the functions of a local authority in the area of PPPs;

- improving the mechanisms of funding PPP projects;

- fostering the development institutions in the PPP management system;

- elimination of contradictions and shortcomings of the legal framework of PPP;

- improvement of cooperation of state (local) authorities with civil society institutions in the implementation of PPP projects (Table 3).

Thus, the above described ways will help to bring the implementation of public-private partnership in Ukraine to a new level. Furthermore, the latest approaches to the management and implementation of public-private partnership should be applied. One of the most promising innovation areas is considered to be the implementation of innovation PPP projects on the basis of cluster approach.

Public-private partnership in Ukraine should become a catalyst for the activity that will contribute to the development of economy and social sphere. The above is very likely to happen, provided legislative determination of legal, economic and organizational basis of PPP functioning in a special law on the general principles of PPP development. After the adoption of a special law, regulatory framework is required for the features of PPP in various sectors of the economy, as well as the legislative improvement of PPP mechanisms (concessions, product sharing agreements, joint activities, etc.) (Pavliuk, 2010).

\section{Conclusions}

Public-private partnership in Ukraine should further be a key factor for socio-economic development in the state, but this requires legislative determination of the legal, economic and organizational basis for the functioning of public-private partnership in a special law, following the adoption of which it would be necessary to set the regulatory framework for the features of PPP in certain sectors of the economy, as well as to improve PPP mechanisms. 


\section{References}

The Database of Public-Private Partnership Projects in the World. The World Bank [Electronic resource]. Retrieved from: http://ppi.worldbank.org/index.aspx.

Braylovsky, I. (2014). The Development of Public-Private Partnership in Ukraine in the Context of the World Trends. Skhid, 1: 6-10.

Butnyk, O.O. The Analysis of the Development of Public-Private Partnership in Ukraine / O.O. Butnyk [Electronic resource]. - Retrieved from: http://www.dy.nayka.com.ua/?op=1\&z=709.

Didchenko, O.I., Public-Private Partnership: the Essence, Legislation, Foreign Expertise [Electronic resource]. Retrieved from: http://www.zgia.zp.ua/gazeta/evzdia_2_048.pdf.

Kalinko, I.V. (2015). Public-Private Partnership: Foreign Expertise and Prospects of Implementation in Ukraine. Scientific Bulletin of Polissia Region, 1 (1): 15-21.

The Concept of the Development of Public-Private Partnership in Ukraine for 2012-2017 [Electronic resource]. Retrieved from: http://ppp-ukraine.org/wp-content/uploads/2015/03/PPP-Development-Concept-2012-2017.pdf.

Maslennikov, O.M. The Problems of the Development of Public-Private Partnership in Ukraine [Electronic resource]. - Retrieved from: http://eprints.kname.edu.ua/32291/1/106.pdf.

Pavlova, H.O. Public-Private Partnership: Analysis of the World Expertise and the Ways of Development in Ukraine [Electronic resource]. - Retrieved from: http://www.kbuapa.kharkov.ua/e-book/putp/2011-3/doc/3/02.pdf.

Pavliuk, K.V. (2010). The Essence and the Role of Public-Private Partnership in Socio-Economic Development of the State. Scientific Works of KNTU, Economic Sciences, (17): 123-133.

The Law of Ukraine “On Public-Private Partnership” dated July 1, 2010. Holos Ukrainy, 2010, July 30 (140): 89-91. Resolution of the Cabinet of Ministers of Ukraine On the Approval of the Concept of the Development of PublicPrivate Partnership in Housing and Communal Services dated September 16, 2009 No. 1184-r [Electronic resource]. - Retrieved from: http://zakon2.rada.gov.ua/laws/show/1184-2009-\%D1\%80.

Resolution of the Cabinet of Ministers of Ukraine On the Approval of the Concept of the Development of PublicPrivate Partnership in Ukraine for 2013-2018 dated August 14, 2013 No. 739-r. [Electronic resource]. - Retrieved from: http://zakon4.rada.gov.ua/laws/show/739-2013-\%D1\%80?test=qY4Mfbtc78fVy6YUZi9OvkEcHI4zgs80 msh8Ie6.

Siduniak, O.V. Public-Private Partnership: Current Condition and Problems of the Development in Ukraine [Electronic resource]. - Retrieved from: http://globalnauka.com/naukova_ukraina/2090.html.

\section{Максим ЛЕВОЧКИН}

\section{ПРОБЛЕМЫ ГОСУДАРСТВЕННО-ЧАСТНОГО ПАРТНЕРСТВА В УКРАИНЕ И ПУТИ ИХ ПРЕОДОЛЕНИЯ}

Аннотация. В статье раскрыта сущность и роль государственно-частного партнерства. Установлено, что государственно-частное партнерство - это эффективный и перспективный инструмент социальноэкономического развития как на региональном, так и на местном уровне, а также средство привлечения средств в проекты. Определены законодательное регулирование государственно-частного партнерства в Украине и его недостатки. Выяснено, что законодательные акты содержат много спорных вопросов, касающихся: проблем коммуникации между партнерами; законодательных и регуляторных проблем; проблем финансирования. Приведено количество проектов ГЧП в Украине по секторам и инвестиции в проекты государственно-частного партнерства. Определено, что в течение 1992-2012 годов в Украине было реализовано 58 проектов ГЧП, или 7,03\% от общей численности реализованных проектов. Изображен структуру реализованных ГЧП проектов в Украине, львиная доля в которой приходится на энергетику (71\%), телекоммуникации (24\%), транспорт (2\%), водоснабжения и водоотведения (3\%). Определены проблемы, которые препятствуют развитию государственно-частного партнерства в Украине, а именно: брак высококвалифицированных специалистов, способных развивать в будущем государственно-частное партнерство - как с стороны предпринимательства, так и страны; брак проектов государственно-частное партнерства и надлежащих банковских требований к ним; не желание предпринимательства стимулировать развитие государственно-частного партнерства, поскольку численность частных операторов незначительна в очень невысоком количестве секторов; неспособность государственных органов к поддержанию партнерских взаимоотношений и выполнения проектов государственно-частного партнерства; недостатки законодательной базы (например, концессионного) и несоответствие правоприменительной деятельности; незначительная активность регионов страны проявлять инициативу в разработке и реализации проектов государственно-частного партнерства; неспособность привлекать инвестиции в длительные проекты государственно-частного партнерства и другие. Раскрыто направления совершенствования реализации 
государственно-частного партнерства в Украине согласно Концепции развития государственно-частного партнерства в Украине, среди которых определение приоритетных сфер деятельности для развития ГЧП; улучшение инвестиционного климата и предпринимательской среды в контексте развития ГЧП; развитие уполномоченного государственного органа, ответственного за развитие ГЧП; усиление функций органов местного самоуправления в сфере ГЧП; совершенствование механизмов финансирования проектов ГЧП; активизация институтов развития в системе управления ГЧП; устранение противоречий и недостатков нормативно-правовой базы ГЧП; совершенствования сотрудничества органов власти с институтами гражданского общества по реализации проектов гЧП. Данная статья предусматривает достижение следующих целей: 1) исследование проблем государственно-частного партнерства в Украине; 2) определение путей их решения. Предметом исследования выступает механизм государственно-частного партнерства, его проблемы и пути их решения. В данной работе были применены такие общенаучные и специальные методы изучения: сравнительно-правовой, исторический, диалектический, аналитико-синтетический, формальнологический, статистический. Результаты. Полученные результаты позволили сформулировать конкретные предложения по преодолению проблем государственно-частного партнерства в Украине. Практическое значение полученных результатов заключается в том, что в статье основательно исследовано положение и проблемы государственно-частного партнерства в Украине. Значение/оригинальность. Данная статья является полностью оригинальным исследованием, носит практический характер и может быть использована для дальнейших научных работ. 